\title{
Comparative study of total phenolic contents, antioxidant and antimicrobial activities of different extracts of Corchorus olitorius L. growing in North Cyprus
}

\author{
Ilkin Yucel SENGUN *1, Ahmet GARGI ${ }^{1}$ \\ ORCID: 0000-0002-9445-5166; 0000-0003-4860-3241
}

${ }^{1}$ Ege University, Engineering Faculty, Food Engineering Department, Izmir/Turkey

\begin{abstract}
In this study, antimicrobial and antioxidant activities as well as total phenolic content of dried leaf extracts of Corchorus olitorius grown in North Cyprus were determined. The total phenolic content, antioxidant and antimicrobial activity of the extracts were determined using the Folin-Ciocalteu, DPPH free radical and broth dilution methods, respectively. The antimicrobial activity of the extracts was tested against eight different microorganisms (Bacillus subtilis ATCC 6037, Listeria monocytogenes Scott A, Enterococcus faecalis ATCC 29212, Staphylococcus aureus 6538P, Bacillus cereus No 8, Escherichia coli O157:H7 ATCC 43895, Escherichia coli ATCC 1103, Salmonella Typhimurium NRRL-B-4420). The highest phenolic content was obtained from ethanol extract as $24.61 \mathrm{mg}$ GAE/g. Water, ethanol and methanol extracts of $C$. olitorius were inhibited the DPPH radical by $17.50 \%, 87.10 \%$ and $86.00 \%$, respectively. MIC values of ethanol and methanol extracts of $C$. olitorius against test cultures were varied between $50.00 \%$ and $6.25 \%$, while no inhibitory effect was observed for water extract. The most susceptible microorganisms to methanol extract of the plant were L. monocytogenes Scott A, E. faecalis ATCC 29212 and B. subtilis ATCC 6037 (MIC value of $6.25 \%$ ). All these results showed that $C$. olitorius extracts are important sources showing antimicrobial and antioxidant properties.
\end{abstract}

Keywords: Corchorus olitorius, antimicrobial, total phenolic content, antioxidant

\section{Kuzey Kıbrıs'ta yetişen Corchorus olitorius L.'nin farklı ekstraktlarının toplam fenolik madde içeriği, antioksidan ve antimikrobiyal aktivitelerinin karşılaştırılması} Özet

Bu çalışmada, Kuzey Kıbrıs'ta yetiştirilen Corchorus olitorius'un kurutulmuş yaprak ekstraktlarının antimikrobiyal ve antioksidan aktiviteleri ile toplam fenolik madde miktarı belirlenmiştir. Ekstraktların toplam fenolik madde miktarı, antioksidan ve antimikrobiyal aktivitesi sirasıyla Folin-Ciocalteu, DPPH serbest radikal ve sıv1 seyreltme yöntemleri kullanılarak belirlenmiştir. Ekstraktların antimikrobiyal aktivitesi, sekiz farklı mikroorganizmaya (Bacillus subtilis ATCC 6037, Listeria monocytogenes Scott A, Enterococcus faecalis ATCC 29212, Staphylococcus aureus 6538P, Bacillus cereus No 8, Escherichia coli O157:H7 ATCC 43895, Escherichia coli ATCC 1103, Salmonella Typhimurium NRRL-B-4420) karşı test edilmiştir. En yüksek toplam fenolik madde miktarı etanol ekstraktından $24.61 \mathrm{mg} \mathrm{GAE} / \mathrm{g}$ olarak belirlenmiştir. C. olitorius'un su, etanol ve metanol ekstraktları DPPH radikalini sirasıyla \%17.50, \%87.10 ve \%86.00 oranında inhibe etmiştir. C. olitorius'un etanol ve metanol ekstraktlarının test kültürlerine karşı MIC değerleri \%50.00 ile \%6.25 arasında değişirken, su ekstraktının herhangi bir engelleyici etkisi gözlenmemiştir. L. monocytogenes Scott A, E. faecalis ATCC 29212 ve B. subtilis ATCC 6037 (\%6.25 MIC değeri), bitkinin metanol ekstraktına karşı en duyarlı mikroorganizmalar olmuştur. Tüm bu sonuçlar, C. olitorius ekstraktlarının antimikrobiyal ve antioksidan özellikler gösteren önemli kaynaklar olduğunu göstermiştir.

Anahtar kelimeler: Corchorus olitorius, antimikrobiyal, toplam fenolik madde, antioksidan

\footnotetext{
* Corresponding author / Haberleşmeden sorumlu yazar: Tel.: +90232 3113028; Fax.: +902323427592; E-mail: ilkin.sengun@ege.edu.tr

(c) Copyright 2020 by Biological Diversity and Conservation Received: x.x.2020; Published: 15.12.2020 BioDiCon. 932-1120
} 


\section{Introduction}

Antimicrobials are commonly used in various areas including food production. Hence, some microorganisms became more resistant to antimicrobial agents and infectious diseases are generally caused by these resistant microorganisms, which make treatment difficult [1]. As an alternative to chemically synthesized antimicrobials, there was a need for effective and reliable antimicrobial agents of plant origin [2]. While many drugs originate from plants, various medicinal plants have been used for many years because of their curative effects on diseases [1]. The use of plant-based preservatives instead of chemically synthesized antimicrobials in foods inhibit microbial growth and prolong the shelf life of foods, as well as providing antioxidant effects due to phenolic contents, and shows positive effects on consumer health by increasing immunoglobulin synthesis [3].

Phenolics are secondary metabolite produced by plants to defend themselves against external threats (microbial, physical etc.) [4]. Phenolic contents of plants depend on environmental conditions and endogenous factors such as salinity, light intensity, bacterial infection, drought, temperature, maturity, organ and genotype [5]. Phenolics can be classified as flavonoids, phenolic acids, tannins, stilbenes, coumarins, ligands, quinones and curcuminoids, depending on the amount and position of the carbon element in their chemical structure [6]. Most of the antioxidant activities of fruits and vegetables are associated with their phenolic compounds. Recently, researches on plants containing phenolic compounds have been increased and it has been determined that they have various effects such as antimicrobial, anti-carcinogenic, antioxidant, anti-inflammatory and reducing chronic diseases [7, 8]. For example, flavonoids protect body cells against the harm brought about by oxygen, delivered as a side-effect of vitality digestion [9]. Thanks to the ability of gallic acid to rummaging free radicals and suppress-amyloid oligomerization, it can reduce nerve damage and cerebrum amyloid neuropathology and increase intellectual capacity [10]. In addition to being used as metal ion chelator and protein-precipitating agent, tannins also have antioxidant properties [11]. Hence, in recent years, consumers increase the demand for natural herbal products [12].

Corchorus olitorius is a green leafy plant belonging to Malvaceae family. It is commonly grown in Africa, Europe and Asia and named as molehiya in North Cyprus [13]. Leaves or whole plant are boiled, dried or freshly used in food [14]. As C. olitorius is rich in substances such as minerals, vitamins, fiber and ascorbic acid that provide cell renewal and energy production, it is also used in the medical field due to its antimicrobial and antioxidant effects [15, 16]. Studies indicate that this herb is used to cure diseases such as diabetes, asthma, diarrhea, back and stomach pain $[17,18]$. There are studies investigating the antimicrobial effect of the extracts of $C$. olitorius obtained with different solvents $[19,20]$. Compounds such as hexadecanoic Acid, 2,4-di tert-butyl phenol, tetratetracontane, isoheptadecanol, ethyl palmitate, 1-eicosanol and 8-heptadecene have been identified in C. olitorius extracts [21].

In addition to the limited number of publications in which the phytochemical properties of $C$. olitorius plant grown in N. Cyprus, there is no study in the literature investigating the antimicrobial effect of this plant in terms of MIC (Minimum inhibition concentration) values. Therefore, in this study, antimicrobial and antioxidant activities as well as total phenolic content of three different extracts obtained from $C$. olitorius by water, ethanol and methanol were investigated.

\section{Materials and methods}

\subsection{Collection and Drying of Sample}

C. olitorius collected in July 2018 from Famagusta, N. Cyprus. The leaves removed from the branch were dried using a local conventional method. Fresh leaves allowed to dry for a week on a clean flat surface in the dark room at $30^{\circ} \mathrm{C}$ and mixed three times a day until drying took place. The dried leaves were powdered in a mortar and stored in sterile jars at room temperature.

\subsection{Extraction of Sample}

In the study, water, ethanol and methanol extracts were obtained. For the preparation of water extract, $500 \mathrm{mg}$ of $C$. olitorius leaf was dissolved in $10 \mathrm{~mL}$ of distilled water and mixed at $25^{\circ} \mathrm{C}$ for $24 \mathrm{~h}$. The prepared suspension was centrifuged at $4000 \mathrm{rpm}$ for $10 \mathrm{~min}$ and filtered through a $0.22 \mu \mathrm{m}$ sterile filter (Minisart Syringe Filter, Cellulose Asetate, Sartorious Stedim Biotech) [22]. For methanol extract, $5 \mathrm{~g}$ of C. olitorius were shaken with $100 \mathrm{~mL}$ of $85 \%$ methanol solution in the shaker (Memmert GF 4931, Germany) at room temperature for $24 \mathrm{~h}$. After filtration, methanol was removed by treating the filtered liquid at $40^{\circ} \mathrm{C}$. methanol and then the extract was diluted with water to $50 \mathrm{~mL}$ [23]. Ethanol extracts were prepared from $10 \mathrm{~g}$ of $C$. olitorius leaves. Extraction was carried out with ethanol and distilled water $(40: 60, \mathrm{v} / \mathrm{v})$ in a ratio of $1: 50(\mathrm{~m} / \mathrm{v}$-solute/solvent), respectively. The medley liquid was shaken with shaker (Memmert GF 4931 , Germany) at $25^{\circ} \mathrm{C}$ for $24 \mathrm{~h}$, then centrifuged at $5000 \mathrm{rpm}$ for $25 \mathrm{~min}$. The clear extracts were taken and dried in a vacuum evaporator at $40^{\circ} \mathrm{C}$ to eliminate ethanol [24]. Then, the final extract was used in the analysis as ethanol extract. 


\subsection{Total Phenolic Content}

Total phenolic content of $C$. olitorus extracts was determined using the Folin-Ciocalteu method. $5 \mathrm{~mL}$ of FolinCiocalteu solution $(10 \%, \mathrm{v} / \mathrm{v})$ and $1 \mathrm{~mL}$ filtered sample were transferred into tube and stored in the dark for 3 min. Then $10 \mathrm{~mL}$ of saturated $\mathrm{NaCO}_{3}$ was added and the mixture was filled to $100 \mathrm{~mL}$ with distilled water. The resulting mixture became ready to be analyzed after being kept at $25^{\circ} \mathrm{C}$ for $90 \mathrm{~min}$ in a non-light environment. Finally, absorbance of the sample was measured by using a spectrophotometer (Agilent Technologies, Carry60 UV-Visible) at $760 \mathrm{~nm}$. The results were taken as mg gallic acid equivalents (GAE)/L [25].

Using the equation below, the results were converted from $\mathrm{mg} \mathrm{GAE} / \mathrm{L}$ to $\mathrm{mg} \mathrm{GAE} / \mathrm{g}$ [26].

$\mathrm{T}(\mathrm{mg} \mathrm{GAE} / \mathrm{g})=(\mathrm{C} \times \mathrm{V}) / \mathrm{M}$

In this formulation, $\mathrm{C}$ is the concentration of the acid in which the results are expressed (gallic acid) $(\mathrm{mg} / \mathrm{mL}), \mathrm{V}$ is the volume of the extract solution $(\mathrm{mL})$, and $\mathrm{M}$ is the weight of the plant extracted $(\mathrm{g})$.

In this formula, $\mathrm{C}$ is the concentration of gallic acid established from the calibration curve in $\mathrm{mg} / \mathrm{mL}, \mathrm{V}$ is the volume of the extract solution in $\mathrm{mL}, \mathrm{M}$ is the weight of the extract in $\mathrm{g}$.

\subsection{Antioxidant Capacity}

DPPH radical scavenging activity method was used to determine the antioxidant activity of $C$. olitorus extracts. $4 \mathrm{~mL}$ of DPPH solution dissolved in methanol was mixed with $0.1 \mathrm{~mL}$ of the filtered sample in a tube. The mixture obtained was kept in non-light environment for 15 minutes before being analyzed in the spectrophotometer (Agilent Technologies, Carry60 UV-Visible) at $517 \mathrm{~nm}$ [27]. The control sample was methanol (1 mL). The obtained DPPH radical scavenging activity results converted to percentage using by this formula:

DPPH scavenging activity $(\%)=($ Ac-As $) / A c \times 100$

In this formula, As and Ac are defined as absorbance of sample and control, respectively.

\subsection{Antimicrobial Activity}

The antimicrobial activity of three different extracts of $C$. olitorus was tested on eight microorganisms including 5 Gram positive (Bacillus subtilis ATCC 6037, Listeria monocytogenes Scott A, Enterococcus faecalis ATCC 29212, Staphylococcus aureus 6538P, Bacillus cereus No 8) and 3 Gram negative (Escherichia coli O157:H7 ATCC 43895, Escherichia coli ATCC 1103, Salmonella Typhimurium NRRL-B-4420) bacteria using broth dilution method. Test cultures obtained from University of Ege, Department of Food Engineering, Laboratory of Food Microbiology Research. Tryptic Soy Broth (TSB, pH 7.3 \pm 0.2 , Oxoid) was used for the activation of glycerol stock cultures and the cultures were activated by incubating at $37^{\circ} \mathrm{C}$ for $24 \mathrm{~h}$. Then, activated cultures were used in the analysis after being adjusted to $0.5 \mathrm{Mc}$ Farland turbidity grade using DEN-1 Mc Farland Densitometer.

To determine MIC (Minimum Inhibitory Concentration) value of each $C$. olitorius extracts, the broth-dilution method was performed by using 96 well ' $U$ ', type sterile microplates [28]. Firstly, a hundred $\mu \mathrm{L}$ of Mueller Hinton Broth (MHB, pH $7.3 \pm 0.2$, Oxoid) turned into brought to all wells, then a hundred $\mu \mathrm{L}$ of extract turned into brought to all wells in horizontal alignment. The amount of the extract was diluted to contain half of the previous well. The extraction rates from the first well were $50 \%, 25 \%, 12.5 \%, 6.25 \%, 3.125 \%, 1.563 \%, 0.781 \%, 0.391 \%, 0.195 \%, 0.098 \%$ (v/v), respectively. $10 \mu \mathrm{L}$ of the culture to be tested was added to the homogenized mixed wells and incubated at $37^{\circ} \mathrm{C}$ for $18 \mathrm{~h}$. After incubation period, each well filled with $20 \mu \mathrm{L}$ of $0.5 \%$ 2,3,5-triphenyltetrazolium chloride and incubated at $37^{\circ} \mathrm{C}$ for $30 \mathrm{~min}$. The lowest concentration that does not cause color change on test cultures was determined as MIC value. The sample taken from the well containing the lowest concentration of extract without growth was used to determine the MBC (Minimum Bactericidal Concentration) value by spreading to Mueller-Hilton Agar (MHA, pH 7.3 \pm 0.2 , Oxoid).

\subsection{Statistical analysis}

The statistical analysis was applied using the one-way ANOVA method, with SPSS 20 package program, at the significance level of $P \leq 0.05$. Results are given as mean and standard deviation [29].

\section{Results}

Solvents such as methanol, acetone, hexane, chloroform, ethyl acetate, ethanol and water are used to obtain extracts from various plants. During extraction, the dissolution of phytochemicals varies according to the type of solvent used. In the other studies, it has been determined that although solvents are recommended for the extraction of phenolic compounds and saponins, water can dissolve non-phenolic antimicrobial substances and also the best option for the extraction of trypsin inhibitors [30]. Besides, water extraction could be preferred due to the safety and environmental concerns. In the study, the total phenolic content of water, ethanol and methanol extracts of $C$. olitorius 
was the highest $(24.61 \mathrm{mg} \mathrm{GAE} / \mathrm{g})$ in ethanol extract, while it was the least $(9.86 \mathrm{mg} \mathrm{GAE} / \mathrm{g})$ in water extract $(P<0.05)$ (Table 1). Besides, no statistical difference was observed between phenolic contents of ethanol and methanol extracts $(P>0.05)$. Hence, ethanol appears to be the most suitable solvent for the dissolution of phenolic compounds of $C$. olitorius. Ademiluyi et al. [31] reported that the total phenolic amount of the water extract of dried leaves of $C$. olitorius grown in Nigeria was determined as $5 \mathrm{mg} \mathrm{GAE} / \mathrm{g}$.

Table 1. Total phenolic content of $C$. olitorius extracts

\begin{tabular}{lc}
\hline Extracts & Total phenolic content (mg GAE/g) \\
\hline Water extract & $9.86 \pm 2.07^{\mathrm{B}}$ \\
Ethanol extract & $24.61 \pm 1.97^{\mathrm{A}}$ \\
Methanol extract & $21.14 \pm 0.69^{\mathrm{A}}$
\end{tabular}

*The capital letters (A, B) in the table show the statistical difference between samples $(P<0.05)$.

It was determined that water, ethanol and methanol extracts of $C$. olitorius inhibited the DPPH radical in the range of $17.50 \%-87.10 \%$ (Table 2). The highest value was observed in ethanol extract, while there were no statistical differences between ethanol and methanol extracts $(P>0.05)$. These results were in parallel with the total phenolic content results. In the study of Yakoub et al. [32] antioxidant activity of water and ethanol extracts of dried leaves of $C$. olitorius grown in Tunisia was $77.64 \%$ and $91.65 \%$, respectively. Obeng et al. [33] investigated the antioxidant activity of $C$. olitorius grown in Ghana after drying the leaves in an oven at $55^{\circ} \mathrm{C}$ for $6 \mathrm{~h}$. The results showed that methanol extract of $C$. olitorius inhibited the DPPH radical by $\% 22.20$, which is very low than our results.

Table 2. Antioxidant activity of $C$. olitorius extracts

\begin{tabular}{lc}
\hline Extracts & DPPH (\%) \\
\hline Water extract & $17.50 \pm 2.59^{\mathrm{B}}$ \\
Ethanol extract & $87.10 \pm 1.41^{\mathrm{A}}$ \\
Methanol extract & $86.00 \pm 0.54^{\mathrm{A}}$ \\
\hline
\end{tabular}

*The capital letters (A, B) in the table show the statistical difference between samples $(P<0.05)$.

Antimicrobial activities of the extracts obtained from $C$. olitorius had been decided against 8 different microorganisms by using broth dilution method. The water extract of $C$. olitorius showed no antimicrobial effect against any of the microorganisms tested. All test cultures had MIC value of $25.00 \%$ against ethanol extract. The results showed that antimicrobial activity of methanol extract is higher than ethanol extract $(P<0.05)$. In addition, the extracts did not show bactericidal effect against any of the microorganisms tested.

Table 3. Antimicrobial activity of $C$. olitorius extracts

\begin{tabular}{lccc} 
Test Microorganisms & MIC value $(\%, \mathbf{v} / \mathbf{v})$ & $\begin{array}{c}\text { Methanol } \\
\text { extract }\end{array}$ \\
\hline L. monocytogenes Scott A & extract & $\begin{array}{c}\text { Ethanol } \\
\text { extract }\end{array}$ & 6.25 \\
E. faecalis ATCC 29212 & $>50$ & 25.00 & 6.25 \\
B. subtilis ATCC 6037 & $>50$ & 25.00 & 6.25 \\
S. aureus 6538P & $>50$ & 25.00 & 12.50 \\
E. coli O157:H7 ATCC 43895 & $>50$ & 25.00 & 12.50 \\
S. Typhimurium NRRL-B-4420 & $>50$ & 25.00 & 12.50 \\
E. coli ATCC 1103 & $>50$ & 25.00 & 12.50 \\
\hline
\end{tabular}


There is no study in the literature in which the antimicrobial effect of $C$. olitorius extracts was determined by MIC analysis. In the study performed by Mohammed [34], C. olitorius was extracted in 96\% ethanol and its antimicrobial effect was examined for four different concentrations $(1.00,0.75,0.50,0.25 \mathrm{mg} / \mathrm{mL})$ by agar diffusion using $10 \mathrm{~mm}$ discs against B. subtilis, E. coli and E. faecalis. Zones formed against B. subtilis, E. coli and E. faecalis are reported as in the range of $18-20 \mathrm{~mm}, 14-20 \mathrm{~mm}$ and $13-15 \mathrm{~mm}$, respectively. In another study, the antimicrobial effects of methanol petroleum ether and ethyl acetate + water extracts of $C$. olitorius harvested in N. Cyprus were determined against twelve different bacteria (B. cereus NRRL B-3711, S. aureus ATCC 25923, Pseudomonas gingeri 3146, B. subtilis NRRL B-209, Enterococcus faecium NRRL B-3502, Micrococcus luteus NRRL-B 1018, E. faecalis ATCC 29212, E. coli ATCC 25922, Enterobacter aerogenes NRRL-B 3567, Proteus vulgaris NRRL B-123, Yersinia enterocolitica, $S$. Typhimurium ATCC 14028) using agar diffusion method with $10 \mathrm{~mm}$ discs and it was observed that the extracts were formed inhibition zones ranging from 10 to $20 \mathrm{~mm}$ [35]. All these results showed that $C$. olitorius have antimicrobial activity in various ranges depending on the test cultures used.

According to the results, the antioxidant and antimicrobial effects of the C. olitorius extracts were different, as well as the total phenolic substance content. This difference is thought to be due to the solvent's ability to dissolve different compounds of the plant.

\section{Conclusions and discussion}

Various compounds found in plants can be extracted by different methods. The performance of extracting process varies according to the solvent and the type of plant used. In the current study, it was observed that as the amount of phenolic content increased, the antimicrobial effect also increased. As similar with our results, the inhibitory effect of $C$. olitorius ethanol extract against test microorganisms was observed in another study [34], which also shows that ethanol is a suitable solvent for extracting the antimicrobial effective compounds from the plant. However, the total phenolic content of $C$. olitorius water extract obtained in another study [31] was almost half of our result. This result may be due to the geographical difference in which the plant grows.

In this study, it was determined that $C$. olitorius extracts have antimicrobial and antioxidant activities as well as rich in total phenolic content. The total phenolic content and antioxidant activity results showed that ethanol extract was the most efficient sample when compared to water and methanol extracts, while antimicrobial activity was the highest in methanol extract against all test cultures. Hence, $C$. olitorius has the potential to be used as an alternative to chemical antimicrobial and antioxidant agents. The results showed that the antimicrobial and bioactive properties of $C$. olitorius may change depending on the geographical region where the plant is grown, the drying processes applied to the plant, as well as solvent type used during plant extraction. In the future studies, $C$. olitorius will be used in various foods for detecting its effect on food quality and safety.

\section{References}

[1] Sabo, V. A., \& Knezevic, P. (2019). Antimicrobial activity of Eucalyptus camaldulensis Dehn. plant extracts and essential oils: A review. Industrial Crops and Products, 132, 413-429. https://doi.org/10.1016/j.indcrop.2019.02.051

[2] Panda, S. K., Mohanta, Y. K., Padhi, L., \& Luyten, W. (2019). Antimicrobial activity of select edible plants from Odisha, India against food-borne pathogens. LWT, 113, 108246. https://doi.org/10.1016/j.lwt.2019.06.013

[3] Tajkarimi, M. M., Ibrahim, S. A., \& Cliver, D. O. (2010). Antimicrobial herb and spice compounds in food. Food Control, 21(9), 1199-1218. https://doi.org/10.1016/j.foodcont.2010.02.003

[4] Maddox, C. E., Laur, L. M., \& Tian, L. (2010). Antibacterial activity of phenolic compounds against the phytopathogen Xylella fastidiosa. Current Microbiology, 60(1), 53. https://doi.org/10.1007/s00284-009-9501-0

[5] Karray- Bouraoui, N. A. J. O. U. A., Ksouri, R., Falleh, H., Rabhi, M., Jaleel, C. A., Grignon, C., \& Lachaal, M. (2010). Effects of environment and development stage on phenolic content and antioxidant activities of Mentha pulegium L. Journal of Food Biochemistry, 34, 79-89. https://doi.org/10.1111/j.1745-4514.2009.00303.x

[6] Mark, R., Lyu, X., Lee, J. J., Parra-Saldívar, R., \& Chen, W. N. (2019). Sustainable production of natural phenolics for functional food applications. Journal of Functional Foods, 57, $233-254$. https://doi.org/10.1016/j.jff.2019.04.008

[7] Zhang, L., Shamaladevi, N., Jayaprakasha, G. K., Patil, B. S., \& Lokeshwar, B. L. (2015). Polyphenol-rich extract of Pimenta dioica berries (Allspice) kills breast cancer cells by autophagy and delays growth of triple negative breast cancer in athymic mice. Oncotarget, 6(18), 16379. https://doi.org/10.18632/oncotarget.3834

[8] Correa, L. B., Pádua, T. A., Seito, L. N., Costa, T. E. M. M., Silva, M. A., Candéa, A. L. P., ... \& Henriques, M. G. (2016). Anti-inflammatory effect of methyl gallate on experimental arthritis: Inhibition of neutrophil 
recruitment, production of inflammatory mediators, and activation of macrophages. Journal of Natural Products, 79(6), 1554-1566. https://doi.org/10.1021/acs.jnatprod.5b01115

[9] Passamonti, S., Vrhovsek, U., Vanzo, A., \& Mattivi, F. (2005). Fast access of some grape pigments to the brain. Journal of Agricultural and Food Chemistry, 53(18), 7029-7034. https://doi.org/10.1021/jf050565k

[10] Hajipour, S., Sarkaki, A., Farbood, Y., Eidi, A., Mortazavi, P., \& Valizadeh, Z. (2016). Effect of gallic acid on dementia type of Alzheimer disease in rats: electrophysiological and histological studies. Basic and Clinical Neuroscience, 7(2), 97. https://doi.org/10.15412/J.BCN.03070203

[11] Kumar, S., Gupta, A., \& Pandey, A. K. (2013). Calotropis procera root extract has the capability to combat free radical mediated damage. International Scholarly Research Notices, 2013. https://doi.org/10.1155/2013/691372

[12] J., \& Pilz, S. (Eds.). (2011). Industrial Scale Natural Products Extraction. Germany: Wiley-VCH.

[13] Yang, Z., Wu, Y., Dai, Z., Chen, X., Wang, H., Yang, S., ... \& Deng, C. (2020). Comprehensive transcriptome analysis and tissue-specific profiling of gene expression in jute (Corchorus olitorius L.). Industrial Crops and Products, 146, 112101. https://doi.org/10.1186/s12864-020-06805-6

[14] Bhandari, H. R., Bera, A., Kar, C. S., \& Biswas, S. (2018). Stability assessment of jute seed production system in lower Gangetic plains of India. Industrial Crops and Products, 125, 505-510. https://doi.org/10.1016/j.indcrop.2018.09.009

[15] Islam, M. M. (2013). Biochemistry, medicinal and food values of jute (Corchorus capsularis L. and C. olitorius L.) leaf: a review. International Journal of Enhanced Research In Science Technology \& Engineering, 2(11), 135-44.

[16] Yan, Y. Y., Wang, Y. W., Chen, S. L., Zhuang, S. R., \& Wang, C. K. (2013). Anti-inflammatory effects of phenolic crude extracts from five fractions of Corchorus Olitorius L. Food Chemistry, 138(2-3), 1008-1014. https://doi.org/10.1016/j.foodchem.2012.10.052

[17] Barku, V., Opoku-Boahen, Y., Owusu-Ansah, E., Dayie, N. T. K. D., \& Mensah, F. (2013). In-vitro assessment of antioxidant and antimicrobial activities of methanol extracts of six wound healing medicinal plants. In-Vitro, $3(1)$.

[18] Kumari, N., Choudhary, S. B., Sharma, H. K., Singh, B. K., \& Kumar, A. A. (2019). Health-promoting properties of Corchorus leaves: A review. Journal of Herbal Medicine, 15, 100240. https://doi.org/10.1016/j.hermed.2018.10.005

[19] Özdenefe, M. S., Muhammed, A., Süer, K., Güler, E., Aysun, H., \& Takc1, M. (2018). Determination of antimicrobial activity of Corchorus olitorius leaf extracts. Cyprus Journal of Medical Sciences, 3(3), 159-164. https://doi.org/10.5152/cjms.2018.623

[20] Abir, R. R., Marjia, M., Rakhi, N. N., Saha, O., Hossain, M. A., \& Rahaman, M. M. (2019). In vitro comparative analysis of antibacterial activity of different fractions of Corchorus capsularis and Corchorus olitorius leaves extracts. Bangladesh Journal of Microbiology, 36(2), 69-73. https://doi.org/10.3329/bjm.v36i2.45530

[21] Al-Yousef, H. M., Amina, M., \& Ahamad, S. R. (2017). Comparative study on the chemical composition of Corchorus olitorius leaf and stem dry oils. Biomedical research, 28(10).

[22] Silván, J. M., Mingo, E., Hidalgo, M., de Pascual-Teresa, S., Carrascosa, A. V., \& Martinez-Rodriguez, A. J. (2013). Antibacterial activity of a grape seed extract and its fractions against Campylobacter spp. Food Control, 29(1), 25-31. https://doi.org/10.1016/j.foodcont.2012.05.063

[23] Hassanpour, H., \& Khoshamad, R. (2017). Antioxidant capacity, phenolic compounds and antioxidant enzymes of wild grape seeds from different accessions grown in Iran. Erwerbs-Obstbau, 59(4), 281-290. https://doi.org/10.1007/s10341-017-0323-0

[24] Corrêa, R. C., Barros, L., Fernandes, Â., Sokovic, M., Bracht, A., Peralta, R. M., \& Ferreira, I. C. (2018). A natural food ingredient based on ergosterol: optimization of the extraction from Agaricus blazei, evaluation of bioactive properties and incorporation in yogurts. Food \& Function, 9(3), 1465-1474. https://doi.org/10.1039/C7FO02007D

[25] Cemeroğlu, B., 2013, Gıda Analizleri, Ankara: Gıda Teknolojisi Derneği Yayınları.

[26] Abdelhady, M. I., Motaal, A. A., \& Beerhues, L. (2011). Total phenolic content and antioxidant activity of standardized extracts from leaves and cell cultures of three Callistemon species. American Journal of Plant Sciences, 2(6), 847. https://doi.org/10.4236/ajps.2011.26100

[27] Naik, D., Dandge, C., \& Rupanar, S. (2014). Determination of chemical composition and evaluation of antioxidant activity of essential oil from Tinospora cordifolia (Willd.) Leaf. Journal of Essential Oil Bearing Plants, 17(2), 228-236. https://doi.org/10.1080/0972060X.2013.831568

[28] Deng, Y., Yang, G., Yue, J., Qian, B., Liu, Z., Wang, D., ... \& Zhao, Y. (2014). Influences of ripening stages and extracting solvents on the polyphenolic compounds, antimicrobial and antioxidant activities of blueberry leaf extracts. Food Control, 38, 184-191. https://doi.org/10.1016/j.foodcont.2013.10.023

[29] SPSS (2011). Statistical package, SPSS for Windows. Ver. 20.0, Chicago.

[30] Le, A. V., Parks, S. E., Nguyen, M. H., \& Roach, P. D. (2018). Effect of solvents and extraction methods on recovery of bioactive compounds from defatted Gac (Momordica cochinchinensis Spreng.) Seeds. Separations, 5 (39). https://doi.org/10.3390/separations5030039 
[31] Ademiluyi, A. O., Oboh, G., Aragbaiye, F. P., Oyeleye, S. I., \& Ogunsuyi, O. B. (2015). Antioxidant properties and in vitro $\alpha$-amylase and $\alpha$-glucosidase inhibitory properties of phenolics constituents from different varieties of Corchorus spp. Journal of Taibah University Medical Sciences, 10(3), $278-287$. https://doi.org/10.1016/j.jtumed.2014.11.005

[32] Yakoub, A. R. B., Abdehedi, O., Jridi, M., Elfalleh, W., Nasri, M., \& Ferchichi, A. (2018). Flavonoids, phenols, antioxidant, and antimicrobial activities in various extracts from Tossa jute leave (Corchorus olitorus L.). Industrial Crops and Products, 118, 206-213. https://doi.org/10.1016/j.indcrop.2018.03.047

[33] Obeng, E., Kpodo, F. M., Tettey, C. O., Essuman, E. K., \& Adzinyo, O. A. (2020). Antioxidant, total phenols and proximate constituents of four tropical leafy vegetables. Scientific African, 7, e00227. https://doi.org/10.1016/j.sciaf.2019.e00227

[34] Mohammed, R. M. O. (2016). Phytochemical investigation of antimicrobial and antioxidant activity leaves extracts of Corchorus olitorius. Open Access Library Journal, 3(1). 1-5. https://doi.org/10.4236/oalib.1102225

[35] Semra, I., Filiz, S., \& Ferdag, C. (2007). Antibacterial and antifungal activity of Corchorus olitorius L. (Molokhia) extracts. International Journal of Natural and Engineering Sciences, 1, 59-61. 